Agricultural Journal 7 (5): 360-364, 2012

ISSN: $1816-9155$

(C) Medwell Journals, 2012

\title{
Utilization and Determinants of Institutional Credit of the NACRDB by Small Scale Farmers in Imo State, Nigeria
}

\author{
${ }^{1}$ J.S. Orebiyi, ${ }^{1}$ C.C. Eze, ${ }^{1}$ A. Henri-Ukoha, ${ }^{1}$ F.C. Akubude, ${ }^{1}$ N.G. Ben-Chendo and ${ }^{2}$ S.J. Ibitoye \\ ${ }^{1}$ Department of Agricultural Economics, \\ Federal University of Technology, Owerri, Imo State, Nigeria \\ ${ }^{2}$ Department of Agricultural Economics and Extension, Kogi State University, Anyigba, Nigeria
}

\begin{abstract}
This study was designed to investigate the utilization of institutional credit among small scale farmers in Imo state. A sample of 40 livestock farmers and 50 food crop farmers were selected by multistage random sampling technique. Data were collected through a well structured questionnaire administered to a total of 90 randomly selected farmers. Data collected were analyzed using descriptive and inferential statistics and ordinary least square multiple regression technique. Results showed that farm income, household size, farming experience, expenditure on labour and level of education are important factors that determine the utilization of institutional credit by farmers while interest rate is not a determinant. This study recommends that credit obtained must be utilized on production activities rather than consumption inorder for the loan obtained to be repaid and on time too.
\end{abstract}

Key words: Income, small scale farmers, credit utilization, institutional credit, Nigeria

\section{INTRODUCTION}

Majority of the chronically hungry in the developing countries are small farmers who produce much of what they eat and are often poor and lack access to adequate land, input and produce markets. Asinobi (2000) who confirmed there are still pockets of hungry and malnourished people confirmed this. Hunger and malnutrition are unacceptable in a world that has both the knowledge and resources to end this human tragedy. Due to population growth, this upward trend in hunger converts into a fall on the Millennium Development Goals (MDG) formula but only from $20-19 \%$ of the population of developing countries. Millennium development goal calls for halving hunger and poverty by 2015 in relation to 1990 (FAO, 2001). Of the eight millennium development goals, eradicating extreme hunger and poverty depends mostly on agriculture. In Nigeria, agriculture provides between $80-90 \%$ of the country's food needs (Odife, 2002) and agriculture supports $>70 \%$ of Africa's population. The sector employs the largest number of workers and generates a significant share of GDP in most countries. The main purposes of agricultural production are to meet food security needs, supply inputs to the agricultural industry and earn foreign currency.

Agricultural growth, therefore is the only panacea to the problem of hunger, food insecurity and development.
Agricultural growth has been on the decline over the years. For instance, agricultural growth in sub-Saharan Africa averaged nearly $3 \%$ over the past 25 years. This is partly attributed to their agro-climatic potential, poor infrastructure and the dismantling of public agricultural institutions for research, extension, credit and marketing (Denning et al., 2009). This low state of agriculture has perpetuated hunger. In Nigeria for instance, increasing poverty levels despite several interventions is a matter of serious concern. For instance, analysis of 2003/2004 data revealed that national poverty incidence was $57.8 \%$ with rural areas having $64.1 \%$ while urban the area was $35.4 \%$. In sub-Saharan Africa, there are still 852 million people that are hungry, 26 million underweight children and $>2$ million people are suffering from malnutrition while $50 \%$ of the women are affected by iron deficiency (FAO, 2003). There is a wide gap between domestic food supply and food demand (Ajibefun, 2003). This situation poses a daunting challenge to the achievement of millennium development goals and therefore calls for guided change as it emanates from low agricultural production.

In Nigeria, the present government emphasizes the transformation of smallholder agriculture from subsistence orientation to market orientation and this requires the availability of adequate capital in form of credit, loan, modern equipment, cash or kind. Kropp and Schmidt (1987) assert that most small scale farmers are poor and

Corresponding Author: A. Henri-Ukoha, Department of Agricultural Economics, Federal University of Technology, Owerri, Imo State, Nigeria 
lack savings and investment culture; besides smallholder farmers have limited access to credit compared to other beneficiaries of credit facilities. However because of low yield and price uncertainty associated with farming in developing economies like Nigeria, farmers have low income, low savings and low investment which results in low output. The small scale farmers have been identified as constituting the greatest force in food production in Nigeria. It is pertinent to note that these farmers are faced with different constraints among which access to credit according to Olomola (1990) is a major militating factor against agricultural production and development in the country. Ejiogu and Onubuogu (2003) noted that credit enables a farmer have access to the production resources thereby helping to break the vicious cycle of poverty. Therefore, farm credit remains the major means of improving farm capital investment. It is one thing however to have access to credit and another to utilize it properly. Many people are of the view that small farmers do not use the loans obtained judiciously. Farmer's co-operatives in Ogun, Oyo and Ondo states used $<40 \%$ of their loans for farming while the rest was used on non-farming activities (Osuntoguna and Oludimu, 1981). If loans are properly used, the farmer is able to derive proceeds from his investments and will raise money enough to repay his borrowed fund. According to Adekanye (1983) loan should be properly utilized to improve the living standard of the poor farmers and better financial position of the lending agency. Farm income will be expanded through more intensive use of tillable acres, adoption of current management practices, investment in modern machinery and equipment complements increased financial leverage from borrowed capital (Johnson, 1982). The Federal Government established the Nigerian Agricultural Cooperative and Rural Development Bank (NACRDB) in order to help resource poor farmers gain more access to credit. In spite of the strategies to increase access and utilization of credit by farmers from formal financial institutions in rural areas the problem still persists $(\mathrm{CBN}$, 2002). Secondly, there is limited information on the utilization of institutional credit from the Nigerian Agricultural Co-operative and Rural Development Bank by small scale farmers in the study area.

In view of this therefore, it has become imperative to analyze the utilization of institutional credit of the NACRDB by small scale farmers and make policy recommendations that will launch agriculture to a higher level. The objective of this study is therefore to describe the socio-economic characteristics of small scale farmers in Imo state; determine the use to which the farmers put the credit obtained from the NACRDB and determine factors influencing credit utilization by farmers in the area.

\section{MATERIALS AND METHODS}

The study was carried out in Imo state. Imo state has 27 local government areas. Multistage random sampling technique was used in the study. Nigerian Agricultural and Rural Development Bank was purposively selected as it is solely established for the purpose of credit to the agricultural sector. A list of loan beneficiaries from the bank was collected from the lending officers of the bank in Owerri comprising 180 farmers as the sampling frame. This list was then stratified into loan beneficiaries for livestock and food crops production, respectively. From this sampling frame, 40 and 50 farmers were randomly selected from both group of farmers livestock and food crops, respectively. The data covered the beneficiaries from 2005-2007 so as to ensure that these loans were mature for repayment.

Data for this study were collected from both primary and secondary sources. Primary data were collected through the use of structured questionnaires. The secondary information were obtained from textbooks, internet, library, journals, magazines, seminar papers, etc. Data were analyzed using simple descriptive statistics such as percentage, means and frequencies and ordinary least square multiple regression technique.

In using the ordinary least square multiple regression technique, four functional forms: linear, semi-log, double $\log$ and exponential equations were tried. The model with the highest value of coefficient of multiple determination $\left(\mathrm{R}^{2}\right)$, highest no of significant variables as well as the significance of the F-test was selected as the lead equation. The model is stated implicitly as:

Where:

$$
\mathrm{CU}=\mathrm{f}\left(\mathrm{X}_{1}, \mathrm{X}_{2}, \mathrm{X}_{3}, \mathrm{X}_{4}, \mathrm{X}_{5}, \mathrm{X}_{6}, \mathrm{X}_{7}, \mathrm{e}\right)
$$

$\mathrm{CU}=$ Total amount of credit utilized $(\mathrm{N})$

$\mathrm{X}_{1}=$ Annual farm income of respondents $(\mathrm{N})$

$\mathrm{X}_{2}=$ Value of interest payment $(\mathrm{N})$

$\mathrm{X}_{3}=$ Level of education (No. of years spent in school)

$\mathrm{X}_{4}=$ Household size $(\mathrm{No})$

$\mathrm{X}_{5}=$ Farming experience (Years)

$\mathrm{X}_{6}=$ Labour expenses $(\mathrm{N})$

$\mathrm{X}_{7}=$ Loan supervision (No. of monthly visits by a credit officer)

$\mathrm{e}=$ Error term

It is expected apriori that:

$$
\mathrm{X}_{1}, \mathrm{X}_{3}, \mathrm{X}_{5}, \mathrm{X}_{7}>0 ; \mathrm{X}_{2}, \mathrm{X}_{4}, \mathrm{X}_{6}<0
$$

\section{RESULTS AND DISCUSSION}

Socio-economic characteristics of the farmers: Table 1 shows the mean age of respondents was 50 years 
indicating that majority of the respondents were middle aged farmers who are still active, vibrant and dynamic and are more likely to adopt innovations better and faster than their older counterparts. As the farmer gets older, his ability to withstand stress reduces, hence lack the stamina to face the tediousness involved in farming. This finding is consistent with the results of Henri-Ukoha et al. (2011). The mean number of years spent in school for those who use bank credit was 7 years indicating that the respondents in the area are moderately educated. Education is an investment in human capital which improving productivity/performance which is able to raise the quality of skill of man, narrow his information gap and increase his allocative abilities thereby leading to more productive performance (Orebiyi, 2000).

Table 1 further showed that the respondents were reasonably experienced. This is indicated in their mean years of experience as 11 years. The implication is that they were well experienced in farming and can therefore understand the need for credit and access it. This could be because their being much experience in farming may have exposed them to the benefits of using credit explained that experience correlates positively with age. The mean household size of the respondents was 6 persons/household. The average family size implies that

Table 1: Socio-economic characteristics of the respondents

\begin{tabular}{|c|c|c|}
\hline Variables & Frequency & Percentage \\
\hline \multicolumn{3}{|l|}{ Age } \\
\hline$<30$ & 0 & 0.00 \\
\hline $30-39$ & 6 & 4.65 \\
\hline $40-49$ & 36 & 35.96 \\
\hline $50-59$ & 45 & 55.10 \\
\hline$\geq 60$ & 3 & 4.34 \\
\hline \multicolumn{3}{|c|}{ Educational level } \\
\hline 0 & 10 & 1.61 \\
\hline $1-6$ & 28 & 5.08 \\
\hline $7-12$ & 38 & 58.27 \\
\hline$\geq 13$ & 14 & 35.03 \\
\hline \multicolumn{3}{|l|}{ Sex } \\
\hline Male & 49 & 54.44 \\
\hline Female & 41 & 45.56 \\
\hline \multicolumn{3}{|c|}{ Farming experience } \\
\hline $1-10$ & 31 & 14.02 \\
\hline $11-20$ & 48 & 75.98 \\
\hline $21-30$ & 11 & 10.00 \\
\hline \multicolumn{3}{|c|}{ Marital status } \\
\hline Married & 75 & 83.33 \\
\hline Single & 4 & 4.44 \\
\hline Widowed & 11 & 12.22 \\
\hline \multicolumn{3}{|c|}{ Household size } \\
\hline $1-3$ & 2 & 2.22 \\
\hline $4-6$ & 52 & 57.78 \\
\hline $7-9$ & 36 & 42.22 \\
\hline \multicolumn{3}{|c|}{ Annual income } \\
\hline $101-200$ & 22 & 13.60 \\
\hline $201-300$ & 48 & 49.39 \\
\hline $301-400$ & 8 & 11.52 \\
\hline $401-500$ & 4 & 7.40 \\
\hline $501-600$ & 8 & 18.08 \\
\hline Total & 90 & 100.00 \\
\hline
\end{tabular}

Field survey data (2009) the farmers spend modest amount on feeding, clothing, children school fees and hospital bills, etc.

However, Ibekwe (2001) observed that households with greater number of family members, especially those not dominated by children are more advantageous because they add more to free labour and this inturn leads to increased production. A reasonable proportion of the respondents who use NACRDB credit/loan beneficiaries were males $54.44 \%$ while $45.56 \%$ were females. This implies that most farmers that benefited more were males. Though male farmers have more capital formation than their female counterparts, they still borrow to augment their capital formation. This is in conformity with Eze (2006).

Table 1 further revealed that the mean annual income was 262,722 (\$1750). This can be described as low income. The higher the level of annual farm income of respondents, the higher will be the likelihood of the amount of credit he would utilize.

Table 2 shows that from the mean annual amount of loan granted of $\# 211,655.56$ obtained by the livestock and food crop farmers from the NACRDB, \#45,106 (23.79\%) was spent on hiring labour, $\# 38,000$ (20.04\%) was utilized in the purchase of fertilizer and pesticides while personal (farmers) medical treatment gulped only \#4,254 (2.24\%). About $10.44 \%$ ( $\# 22,096)$ could not be accounted for by the farmers probably indicating the level of loan diversion which is very low in this case. This implies that the loan was utilized for agricultural activities. This is line with the findings of Henri-Ukoha et al. (2011) that farmers in Ohafia utilize their loan for agricultural activities as the rate of loan diversion is $12 \%$.

Factors influencing credit utilization of small scale farmers: To identify the factors that determine credit utilization by small scale-farmers, four functional forms of the multiple regression model were fitted into the field data as shown in Table 3 . Table 3 shows that the double $\log$ function was chosen as the lead equation, based on

Table 2: Utilization of credit obtained from the Nigerian Agricultural

\begin{tabular}{lcc}
\multicolumn{3}{c}{ Co-operative and Rural Development Bank (NACRDB) } \\
\hline & $\begin{array}{c}\text { Amount of credit } \\
\text { loan used (N) }\end{array}$ & Loan used (\%) \\
Purpose of loan & 45,106 & 23.79 \\
Labour hiring & 26,199 & 13.82 \\
Land rented & 38,000 & 20.04 \\
Fertilizers and pesticides & 8,000 & 4.22 \\
Purchase of chemical & 42,000 & 22.15 \\
Livestock feeds and drugs & 18,000 & 0.42 \\
Farm tools and implements & 8,000 & 4.22 \\
Children education & 4,254 & 2.24 \\
Medical treatment & 189,559 & 100.00 \\
Total & &
\end{tabular}

Field survey data (2009) 
Agric. J., 7 (5): 360-364, 2012

Table 3: Estimate of multiple regression result of factors influencing credit utilization by farmers

\begin{tabular}{lllll}
\hline Variables & Linear form & Semi log form & Double log form & Exponential form \\
\hline $\mathrm{X}_{1}$ (Farm income) & $4.1729(1.9951)^{* *}$ & $2.0887(1.1008)$ & $0.0733(3.3470)^{* * *}$ & $0.0071(2.5357)^{* *}$ \\
$\mathrm{X}_{2}$ (Value of interest payment) & $-8.1927(-1.0785)$ & $-4.1164(-1.2847)$ & $-0.0614(-1.1607)$ & $-0.0055(-1.1702)$ \\
$\mathrm{X}_{3}$ (Education) & $5.9311(3.0158)^{* *}$ & $3.8126(1.2714)$ & $0.0891(3.5783)^{* * *}$ & $-0.0059(4.5385)^{* * *}$ \\
$\mathrm{X}_{4}$ (HH size) & $-18.1047(1.0719)$ & $-3.0907(2.7573)^{* * *}$ & $-0.0742(-3.2832)^{* * *}$ & $-0.0016(-1.0667)$ \\
$\mathrm{X}_{5}$ (Farming experience) & $14.3908(3.5043)^{* *}$ & $2.6697(1.0662)$ & $0.0964(3.1197)^{* * *}$ & $0.0089(3.0689)^{* * *}$ \\
$\mathrm{X}_{6}$ (Expenditure on labour) & $-10.8617(-1.1929)$ & $-2.1168(-1.0721)$ & $-0.8882(-2.8918)^{* * *}$ & $-0.0013(-1.8571)$ \\
$\mathrm{X}_{7}$ (Loan Supervision) & $11.5903(1.1208)$ & $2.1709(1.1055)$ & $-0.0713(2.9585)^{* * *}$ & $0.0082(3.5652)^{* * *}$ \\
Constant & 189.2217 & 143.0068 & 100.3389 & 81.2695 \\
$\mathrm{R}^{2}$ & 0.5023 & 0.4128 & 0.8122 & 0.6028 \\
$\mathrm{~F}$-value & $11.7635^{* *}$ & $8.1905^{* * *}$ & $50.4472^{* * *}$ & $17.9405^{* * *}$ \\
$\mathrm{~N}$ & 90 & 90 & 90 & 90 \\
\hline
\end{tabular}

*Significant at 5\%, **at $1 \%$; Field survey data (2009)

having the highest value of the coefficient of multiple determination $\left(\mathrm{R}^{2}\right)$, conformity with apriori expectations and having more significant variable coefficients.

The results showed that farm income $\left(\mathrm{X}_{1}\right)$, level of education $\left(\mathrm{X}_{3}\right)$, farming experience $\left(\mathrm{X}_{5}\right)$ and loan supervision $\left(\mathrm{X}_{7}\right)$ were significant at $1 \%$ while the coefficient of level of education $\left(\mathrm{X}_{4}\right)$ was significant at $5 \%$, hence the greater they are, the higher the credit utilized by the farmers. Also, it implies that these variables are important factors influencing the amount of credit utilization by the small scale farmers in the study area. This finding agrees with that of Orebiyi and Ben Chendo (2005) and disagrees with those of Ohajianya and Onyenweaku (2003) who found a positive relationship between income and amount of credit utilized. The coefficients of household size $\left(\mathrm{X}_{4}\right)$ and expenditure on labour $\left(\mathrm{X}_{8}\right)$ were negative and significant at $1 \%$ implying that the higher they are, the higher the amount of credit utilized by the small scale farmers.

However, value of interest payment $\left(\mathrm{X}_{2}\right)$ was negative and not significant, hence was ignored as it is not an important factor influencing credit utilization by small scale farmers from the area. $\mathrm{R}^{2}$ (coefficient of multiple determination) was found to be 0.8122 implying that $81 \%$ of the variability in the amount of credit utilized by farmers was explained by the combined effect of the independent variables.

\section{CONCLUSION}

From the findings of this study, the Nigerian Agricultural Co-operative and Rural Development Bank disbursed some funds for the farmers in the area which was mostly utilized for agricultural production while little fund was diverted to non-agricultural activities. Farm income, level of education, household size, farming experience and expenditure on labour were found to be important determinants for credit usage by farmers in the study area. Credit still plays an important role in promoting better farm income in the study area.

\section{RECOMMENDATION}

The findings reveal that despite full utilization of the funds disbursed to the farmers, there is limited funds altogether. Therefore, it is recommended that the bank should disburse more loanable and reliable funds to improve their output level, enhance food security and improve employment opportunities in rural areas.

\section{REFERENCES}

Adekanye, T.O., 1983. Agricultural credit in Africa: Implications of the Nigerian Experience. Agric. Administration, 14: 203-211.

Ajibefun, A.I., 2003. Determinants of technical efficiency in traditional agricultural production: Application of stochastic frontier modeling to food crop farmers in South-Western Nigeria. Afr. J. Econ. Policy, 10: 31-36.

Asinobi, C., 2000. Household Food Security Level as Assessed by Dietary Intake and Anthropometry of Preschool Children in Cassava Producing Areas of Nigeria. In: Agricultural Transformation in Nigeria, Nwosu A.C., C.U. Nwajiuba and J.A. Mbanasor (Eds.). Novelty Industrial Enterprises, Imo State, Nigeria, pages: 236.

CBN, 2002. Central bank of Nigeria. Annual Report and Statement of Accounts For the Year Ended.

Denning, G., P. Kabambe, P. Sanchez, A. Malik and R. Flor et al., 2009. Input subsidies to improve smallholder maize productivity in Malawi: toward an African Green Revolution. PLOS Biol., Vol. 7. 10.1371/journal.pbio.1000023.

Ejiogu, A.O. and A. Onubuogu, 2003. Assessment of the lending interest rates of the traditional credit and savings association of rice farmers in Imo State. Proceeding of the 37 th Annual Conference of the Agricultural Society of Nigeria, November, 16-20, 2003, University of Calabar, Nigeria, pp: 71-76.

Eze, C.C., 2006. Determinant's of women's access to credit from selected commercial banks in Imo State. Int. J. Nat. Appl. Sci., 2: 136-141. 
FAO, 2001. The State of Food Insecurity in the World.

3rd Edn., Food and Agriculture Organization, Rome, Italy, ISBN:13-9789251046289, Pages: 58.

FAO, 2003. Food and Agriculture Organization. The State of Food Insecurity in the World, FAO, Rome.

Henri-Ukoha, A., J.S. Orebiyi, P.C. Obasi, N.N.O. Oguoma, D.O. Ohajianya, U.U. Ibekwe and I.I. Ukoha, 2011. Determinants of loan acquisition from the financial institutions by small-scale farmers in Ohafia Agricultural Zone of Abia State, South East-Nigeria. J. Dev. Agric. Econ., 3: 67-74.

Ibekwe, U.C., 2001. Income distribution among farm households in orlu agricultural zone of Imo State, Nigeria. Ph.D. Thesis, University of Nigeria, Nsukka, Nigeria.

Johnson, D.T., 1982. The Business of farming: A guide to farm management in the Tropics. The Macmillan Press Ltd., London Basing Stokes, London.
Ohajianya, D.O. and C.E. Onyenweaku, 2003. Demand for Community Bank Credit by small holder farmers in Imo State, Nigeria. J. Sustainable Trop. Agric. Res., 7: 26-32.

Olomola, A.S., 1990. Loan transaction cost and repayment performance and small scale farmers in Ondo State, Nigeria. Ph.D. Thesis, Department of Agricultural Economics, University of Ibadan Nigeria.

Orebiyi, J.S. and N.G. Ben-Chendo, 2005. Determinants of rural agricultural financing by the united bank for Africa and the need for extension services in Imo State, Nigeria. J. Global Approaches Extension Practices (GAEP), 1: 97-102.

Orebiyi, J.S., 2000. The performance of rural credit markets in imo State, Nigeria. Ph.D Thesis, Federal University of Technology, Owerri

Osuntoguna, A. and O. Oludimu, 1981. Extending agricultural credit through public institutions in Nigeria: A comparative study of the Ondo State agricultural development corporation and the Ogun State agricultural development corporation. Farm Economist, 10: 85-97. 